\title{
Meningkatkan Hasil Belajar Siswa pada Mata Pelajaran Pendidikan Kewarganegaraan dengan Metode Diskusi di Kelas VI SDN. No. 035/XI Larikkemahan Tahun 2016/2017
}

\author{
Yenni Hustita ${ }^{1}$ \\ Kepala Sekolah di SDN. No. 035/XI Larikkemahan ${ }^{1}$ \\ Kecamatan Hamparan Rawang, Kota Sungai Penuh, Provinsi Jambi
}

\begin{abstract}
This study is a classroom action research that conducted in two cycles and each cycle consists of four activities namely planning, implementation, observation, and reflection. This study aims to improve student learning outcomes by the method of discussion on the civic education subjects, especially about Government System in Republic of Indonesia. The study was conducted from July to November 2016. This study involved 10 students of sixth grade at SDN. No. 035/XI Larikkemahan, Hamparan Rawang Subdistrict, Sungai Penuh City, Jambi Province. The data was collected is data of learning outcomes collected through test and observation. The data was analyzed by using descriptive analysis and simple statistical test. The results showed that the discussion method successfully improve student learning outcomes. Before the action, students earned an average grade of 54,0. After the action, the average grade increased to 66,0 (Cycle I) and 76,0 (Cycle II). The percentage of students who were able to fulfill the minimum criteria also increased. Before the action, the percentage of students who were able to fulfill the minimum criteria is 30,0\%. Once given the action, the percentage of students who are able to fulfill the minimum criteria increases to 60,0\% (Cycle I) and 80,0\% (Cycle II). Thus, the method of discussion can improve student learning outcomes on the subject of Citizenship Education, especially about Government System in Republic of Indonesia.
\end{abstract}

Keywords: civic education, discussion methods, elementary school, learning activities, learning outcomes

\section{PENDAHULUAN}

Undang-undang Nomor 20 tahun 2003 tentang sistem Pendidikan Nasional pada pasal 1 ayat 1 menyatakan bahwa "Pendidikan adalah usaha sadar dan terencana untuk mewujudkan suasana belajar dan proses pembelajaran agar peserta didik secara aktif mengembangkan potensi dirinya untuk memiliki kekuatan spiritual keagamaan, pengendalian diri, kecerdasan dan akhlak mulia serta keterampilan yang diperlukan dirinya, masyarakat, bangsa dan negara". Lebih lanjut dijelaskan tentang fungsi dan tujuan pendidikan yang tercantum pada pasal (3) yang menyatakan bahwa Pendidikan Nasional berfungsi mengembangkan kemampuan dan membentuk watak serta peradaban bangsa yang bermartabat dalam rangka mencerdaskan kehidupan bangsa bertujuan untuk berkembangnya potensi peserta didik agar menjadi manusia yang beriman dan bertaqwa kepada Tuhan yang Maha Esa, berakhlak mulia, sehat berilmu, cakap, kreatif, mandiri dan menjadi warga Negara yang demokratis serta bertanggungjawab. Sehubungan dengan ini, semua mata pelajaran yang diberikan di sekolah diharapkan mampu memberi kontribusi bagi terbentuknya manusiamanusia Indonesia yang sesuai dengan tujuan pendidikan nasional tersebut.

Salah satu mata pelajaran wajib yang harus dipelajari oleh semua pelajar di Indonesia adalah Pendidikan Kewarganegaraan. Pendidikan Kewarganegaraan (PKn) merupakan salah satu mata pelajaran wajib yang memegang peranan penting dalam pendidikan nasional. Mata pelajaran ini diajarkan 
mulai dari Sekolah Dasar sampai dengan Perguruan Tinggi. Mata pelajaran ini memiliki peran yang strategis dalam mempersiapkan warganegara yang cerdas, bertanggung jawab dan berkeadaban (Kaelan, 2016).

Salah satu indikator tercapai atau tidaknya suatu proses pembelajaran adalah hasil belajar. Menurut Dimyati dan Mudjiono (2013), hasil belajar adalah hasil yang ditunjukkan dari suatu interaksi tindak belajar dan biasanya ditunjukkan dengan nilai tes yang diberikan guru. Hasil belajar dapat diartikan juga sebagai suatu perubahan yang terjadi pada individu yang belajar, bukan hanya perubahan mengenai pengetahuan, tetapi juga untuk membentuk kecakapan, kebiasaan, pengertian, penguasaan dan penghargaan dalam diri seseorang yang belajar (Sudjana, 2005). Hasil belajar juga dapat didefinisikan sebagai kemampuan yang dimiliki siswa setelah menerima pengalaman belajar (Rusman, 2011). Hasil dari kegiatan belajar ditandai dengan adanya perubahan perilaku ke arah positif yang relatif permanen pada diri orang yang belajar.

Guru Pendidikan Kewarganegaraan menemukan masalah rendahnya hasil belajar siswa kelas VI SDN. No 035/XI Larikkemahan, Kecamatan Hamparan Rawang, Kota Sungai Penuh. Hasil pengamatan menunjukkan bahwa siswa hanya duduk diam mendengarkan guru menyajikan materi. Metode yang digunakan guru dalam mengajar adalah metode ceramah sehingga kegiatan pembelajaran hanya berpusat pada guru. Penggunaan metode ini cenderung membuat siswa kurang bersemangat, tidak tertarik, dan bersikap pasif. Akibatnya, hasil belajar siswa cenderung rendah. Hasil tes penjajakan menunjukkan bahwa nilai rata-rata yang diperoleh sepuluh orang siswa kelas VI SDN. No 035/XI Larikkemahan pada mata pelajaran PKn adalah 54,0. Nilai ini masih lebih kecil dibandingkan dengan Kriteria Ketuntasan Minimum (KKM) kompetensi dasar untuk mata pelajaran PKn yaitu 65. Ketuntasan belajar yang dapat dicapai siswa hanya $30,0 \%$. Hasil ini menunjukkan bahwa hanya ada tiga orang siswa yang tuntas yang memperoleh nilai lebih besar daripada nilai KKM kompetensi dasar. Kondisi ini mengindikasikan bahwa hasil belajar siswa pada mata pelajaran PKn kelas VI SDN. No 035/XI Larikkemahan masih rendah.

Hasil belajar yang rendah menunjukkan bahwa tujuan pembelajaran tidak tercapai. Salah satu upaya yang dapat dilakukan untuk mengatasi masalah tersebut adalah dengan cara memperbaiki kualitas pembelajaran melalui pemilihan metode pembelajaran yang tepat. Metode pembelajaran merupakan sebuah perencanaan dan pelaksanaan prosedur dan langkah-langkah pembelajaran yang tersusun secara teratur untuk melakukan proses pembelajaran sampai pada metode penilaian atau evaluasi yag akan dilaksanakan (Sugiyono dan Hariyanto, 2011). Irham dan Wiyani (2013) mengemukakan ada beberapa contoh metode yang dapat digunakan dalam kegiatan pembelajaran yaitu metode ceramah, metode latihan, metode diskusi dan Tanya jawab, metode karyawisata, metode demonstrasi, metode sosiodrama dan bermain peran, metode pemberian tugas dan resitasi, metode eksperimen, dan metode proyek.

Hasil penelitian menunjukkan bahwa metode yang dapat digunakan untuk meningkatkan hasil belajar siswa pada mata pelajaran Pendidikan Kewarganegaraan adalah dengan metode diskusi. Djamarah dan Zain (2006) mendefinisikan metode diskusi sebagai cara penyajian pelajaran yang mana siswa dihadapkan kepada suatu masalah yang bisa berupa pernyataan atau pertanyaan yang bersifat problematis untuk dibahas dan dipecahkan bersama. Metode diskusi diaplikasikan dalam proses belajar mengajar untuk mendorong siswa berpikir kritis, mendorong siswa mengekspresikan 
pendapatnya secara bebas, mendorong siswa menyumbangkan buah pikirannya untuk memecahkan masalah bersama, dan mengambil satu alternatif jawaban atau beberapa alternatif jawaban untuk memecahkan masalah berdasarkan pertimbangan yang seksama (Hosnan, 2014).

Metode ini dipilih dengan mempertimbangkan kelebihannya. Menurut Djamarah dan Zain (2006), kelebihan dari metode diskusi adalah metode ini dapat merangsang kreativitas siswa dalam bentuk ide, gagasan-prakarsa, dan terobosan baru dalam pemecahan suatu masalah, mengembangkan sikap menghargai pendapat orang lain, memperluas wawasan, dan membina untuk terbiasa musyawarah untuk memperkuat dalam memecahkan masalah. Selain itu, hasil penelitian sebelumnya juga menyebutkan bahwa metode diskusi dinilai efektif untuk meningkatkan hasil belajar siswa pada mata pelajaran Pendidikan Kewarganegaraan (Asniar, Harun, \& Septiwiharti, 2013; Astute, Imran, \& Septiwiharti, 2014; Ahadang, Saneba, \& Hasdin, 2014; Firawati, Imran, \& Septiwiharti, 2014; Mimiati, 2015; Sumarni, Harun, \& Imran, 2015). Hal ini dapat terjadi karena metode diskusi dapat meningkatkan perhatian siswa dalam kegiatan pembelajaran (Amu, Jamaludin, \& Hasdin,2014), minat siswa dalam kegiatan pembelajaran (Lanasir, Palimbong, \& Hasdin, 2014), dan pemahaman siswa siswa dalam kegiatan pembelajaran (Libuka, Palimbong, \& Jamaludin, 2014).

Berdasarkan pemaparan tersebut, penulis tertarik untuk melakukan penelitian yang berjudul "Meningkatkan Hasil Belajar Siswa pada Mata Pelajaran Pendidikan Kewarganegaraan khususnya materi sistem pemerintahan di Republik Indonesia dengan Metode Diskusi di Kelas VI SDN. No. 035/XI Larikkemahan tahun 2016/2017'. Penelitian ini bertujuan untuk meningkatkan hasil belajar siswa kelas VI
SDN. No. 035/XI Larikkemahan tahun 2016/2017 dengan menggunakan metode diskusi pada mata pelajaran pendidikan kewarganegaraan, khususnya pada materi sistem pemerintahan di Republik Indonesia.

\section{METODE PENELITIAN}

Penelitian ini merupakan penelitian tindakan kelas. Penelitian tindakan kelas ini dilaksanakan dalam dua siklus yaitu siklus I dan siklus II. Setiap siklus dilakukan sebanyak dua kali pertemuan. Masing-masing siklus terdiri atas empat kegiatan, yaitu perencanaan, pelaksanakan, pengamatan, dan refleksi.

Penelitian dilakukan di SDN. No. 035/XI Larikkemahan, Kecamatan Hamparan Rawang, Kota Sungai Penuh, Provinsi Jambi. Kegiatan penelitian terdiri atas penyusunan proposal penelitian, pengumpulan data, pengolahan data, analisis data, dan penyusunan laporan. Penelitian dilakukan sejak bulan Juli sampai dengan bulan November tahun 2016.

Subjek dalam penelitian ini adalah 10 orang siswa kelas VI semester ganjil tahun pelajaran 2016/2017 di SDN. No. 035/XI Larikkemahan, Kecamatan Hamparan Rawang, Kota Sungai Penuh, Provinsi Jambi. Objek dalam penelitian ini adalah peningkatan hasil belajar siswa kelas VI SDN. No. 035/XI Larikkemahan pada mata pelajaran Pendidikan Kewarganegaraan, khususnya pada materi Sistem Pemerintahan Republik Indonesia: Pemilihan Umum, Pemilihan Presiden dan Wakil Presiden, serta Pemilihan Kepala Daerah dan Wakil Kepala Daerah.

Data yang dikumpulkan dalam penelitian tindakan kelas ini adalah data hasil belajar siswa. Hasil belajar siswa diperoleh melalui evaluasi jenis tes dan non-tes. Evaluasi hasil belajar jenis tes merupakan cara untuk melakukan proses penilaian dalam bentuk tugas atau serangkaian tugas yang harus dikerjakan siswa atau sekelompok siswa sehingga 
menghasilkan suatu nilai yang menggambarkan prestasi siswa. Dalam penelitian ini, tes bertujuan untuk mengukur hasil belajar siswa dengan cara guru memberikan pertanyaan-pertanyaan yang harus dijawab atau perintah-perintah yang harus dijalankan oleh siswa. Setelah itu, guru memberikan penilaian terhadap hasil tes yang diperoleh siswa dengan cara menghitung nilai rata-rata kelas dan juga persentase ketuntasan belajar. Selanjutnya, evaluasi hasil belajar jenis nontes yang digunakan adalah pengamatan atau observasi. Observasi merupakan cara untuk menghimpun data atau bahan-bahan keterangan yang dilakukan dengan mengadakan pengamatan dan pencatatan secara sistematis terhadap fenomenafenomena yang sedang dijadikan sasaran pengamatan. Dalam penelitian ini, observasi dilakukan untuk mengamati tingkah laku siswa selama proses pembelajaran berlangsung. Observasi dilakukan untuk mengetahui keaktifan siswa dalam melakukan skenario pembelajaran. Hasil observasi digunakan untuk mengetahui proses pembelajaran dan untuk memperbaiki kualitas pembelajaran.

Data yang dikumpulkan diolah dan dianalisis untuk mengetahui efektifitas dan tingkat keberhasilan suatu tindakan dengan menggunakan uji statistik sederhana. Uji statistik digunakan untuk menghitung nilai rata-rata kelas dan persentase ketuntasan belajar siswa mulai dari pratindakan, siklus I, dan siklus II. Selanjutnya, nilai rata-rata dan persentase ketuntasan belajar siswa yang diperoleh dianalisis. Analisis dilakukan dengan cara membandingkan nilai rata-rata yang diperoleh siswa sebelum dan sesudah tindakan.

Indikator keberhasilan dari penelitian tindakan kelas ini adalah peningkatan hasil belajar siswa pada mata pelajaran pendidikan kewarganegaraan di kelas VI SDN. No. 035/XI Larikkemahan tahun 2016/2017. Hasil belajar yang diperoleh setiap siswa dibandingkan dengan Kriteria Ketuntasan Minimum (KKM) kompetensi dasar mata pelajaran pendidikan kewarganegaraan yang telah ditentukan oleh sekolah diawal tahun pelajaran 2016/2017 yaitu sebesar 65,0.

\section{HASIL DAN PEMBAHASAN Pratindakan}

Hasil belajar siswa berdasarkan tes penjajakan disajikan pada Tabel 1. Hasil penelitian menunjukkan bahwa nilai yang diperoleh siswa berada pada rentang 40,0070,00 . Artinya, nilai terendah yang diperoleh siswa adalah 40,00 dan nilai tertinggi yang diperoleh siswa adalah 70,00 . Siswa yang terlibat dalam penelitian ini berjumlah 10 orang. Nilai rata-rata yang diperoleh siswa adalah 54,00. Apabila nilai yang diperoleh siswa dibandingkan dengan nilai KKM kompetensi dasar, maka diperoleh hasil bahwa hanya ada tiga orang siswa yang memenuhi KKM Kompetensi Dasar. Dengan demikian, ketuntasan belajar siswa adalah $30,0 \%$.

Tabel 2 Hasil tes penjajakan

\begin{tabular}{clccl}
\hline No & \multicolumn{1}{c}{ Nama Siswa } & KKM & Nilai & \multicolumn{1}{c}{ Keterangan } \\
\hline 1 & Bunga Rahmanora & 65,00 & 40,00 & Tidak Tuntas \\
2 & Dela Juliana & 65,00 & 50,00 & Tidak Tuntas \\
3 & Indah Rahayu Dwi Putri & 65,00 & 50,00 & Tidak Tuntas \\
4 & Kevin Isra Maulana & 65,00 & 40,00 & Tidak Tuntas \\
5 & Pazila Satrianis & 65,00 & 70,00 & Tuntas \\
6 & Putri Habibah & 65,00 & 70,00 & Tuntas \\
7 & Putri Silvi Ramadani & 65,00 & 40,00 & Tidak Tuntas \\
8 & Radit Gustira & 65,00 & 60,00 & Tidak Tuntas \\
9 & Rahmat Hadi Pratama & 65,00 & 50,00 & Tidak Tuntas
\end{tabular}


10 Zafit Wahyu Oktoria

Nilai Tertinggi

Nilai Terendah

Nilai Rata-Rata

Ketuntasan Belajar

$\begin{array}{ccc}65,00 & 70,00 \quad \text { Tuntas } \\ & 70,00 & \\ & 40,00 \\ & 54,00 & \\ & 30,00 \% & \end{array}$

\section{Siklus I}

Kegiatan penelitian pada siklus I dilaksanakan pada hari Kamis, 8 September 2016 (Pertemuan ke-1 Siklus I), hari Kamis, 15 September 2016 (Pertemuan ke2 Siklus I), dan hari Sabtu, 17 September 2016 (Evaluasi Hasil Belajar Siklus I). Kegiatan penelitian pada siklus I terdiri atas perencanaan, pelaksanaan, pengamatan, dan refleksi.

Pertama, perencanaan. Kegiatan perencanaan terdiri atas: merumuskan tujuan pembelajaran, memilih dan mengorganisasi materi ajar, memilih sumber belajar/media pembelajaran, menyusun skenario/kegiatan pembelajaran, dan menyiapkan alat evaluasi hasil belajar.

Kedua, pelaksanaan. Penelitian tindakan kelas dilakukan pada pembelajaran Pendidikan Kewarganegaraan khususnya sub-materi dari Sistem Pemerintahan Republik Indonesia yaitu Pemilihan Umum, Pemilihan Presiden dan Wakil Presiden, serta Pemilihan Kepala Daerah dan Wakil Kepala Daerah. Materi yang disampaikan dalam siklus I adalah Pemilihan Umum yaitu Asas dalam Pemilihan Umum (pertemuan ke-1 Siklus I) dan Tahapan dalam Pemilihan Umum (pertemuan ke-2 Siklus I). Kegiatan dilaksanakan dalam tiga tahap yaitu kegiatan awal, kegiatan inti, dan kegiatan akhir. Kegiatan awal, terdiri atas: guru mengucapkan salam dan menanyakan keadaan siswa, guru mengecek kehadiran siswa, guru menyampaikan tujuan pembelajaran, dan guru menyampaikan skenario pembelajaran yang akan dilaksanakan. Kegiatan inti, terdiri atas: guru menjelaskan masalah yang akan didiskusikan, siswa membentuk kelompok dengan anggota 4-5 orang dan menunjuk satu orang siswa untuk menjadi pemimpin diskusi, siswa melakukan diskusi secara berkelompok, guru mendampingi siswa selama kegiatan diskusi berlangsung, siswa membuat laporan tentang hasil diskusi, setiap perwakilan kelompok menyampaikan hasil diskusi ke depan kelas, dan siswa menanggapi presentasi kelompok lain. Kegiatan penutup, terdiri atas: guru bersama siswa membuat kesimpulan pembelajaran, guru menyampaikan gambaran materi pelajaran selanjutnya, guru menyampaikan pesan moral.

Ketiga, pengamatan. Menurut Sudijono (2005), pengamatan atau observasi adalah cara untuk menghimpun data atau bahan-bahan keterangan yang dilakukan dengan mengadakan pengamatan dan pencatatan secara sistematis terhadap fenomena-fenomena yang sedang dijadikan sasaran pengamatan. Secara ringkas, hasil pengamatan menunjukkan bahwa siswa telah membentuk kelompok-kelompok diskusi. Kelompok yang terbentuk terdiri atas dua kelompok yang setiap kelompok beranggotakan lima orang siswa. Setiap kelompok juga telah memilih salah satu siswa sebagai ketua kelompok dan pemimpin diskusi. Sebagian siswa telah berani untuk menyampaikan pendapatnya untuk menjawab pertanyaan yang diberikan oleh guru. Penyebab siswa tidak berani menjawab pertanyaan guru karena siswa memang tidak tahu jawabannya dan sebagiannya lagi karena takut jawaban yang diberikan salah. Dengan demikian, guru perlu memberikan motivasi untuk meningkatkan kepercayaan diri pada siswa. Sebagian siswa telah membaca materi yang 
akan didiskusikan bersama teman sekelompoknya. Sebagiannya lagi tidak membaca dan lebih cenderung memperhatikan aktivitas teman yang lain. Hal ini menunjukkan bahwa siswa tidak memahami tugas yang seharusnya dikerjakan. Dengan demikian, guru perlu mendekati siswa dan membimbing siswa untuk membaca materi sehingga siswa tersebut dapat berpartisipasi aktif dalam diskusi.

Hasil pengamatan juga menunjukkan bahwa siswa yang telah membaca materi diskusi sebelumnya cenderung berpartisipasi aktif dalam kegiatan diskusi. Siswa yang lebih paham menjelaskan materi yang kurang dipahami oleh teman sekelompoknya. Siswa yang aktif dalam diskusi juga mampu mencatat hasil dari diskusi yang dilakukan. Siswa yang tidak membaca materi, cenderung tidak aktif dalam diskusi dan tidak tahu apa yang harus dicatat dan mereka cenderung menyalin hasil temannya tanpa mengetahui maksud dari catatan yang mereka salin. Semua kelompok telah mampu menyusun hasil diskusi dan mengumpulkan hasil diskusi ke guru. Sebagian besar siswa telah berani untuk mempresentasikan hasil diskusi di depan kelas. Sebagian siswa telah mampu menuliskan kesimpulan pembelajaran. Hasil pengamatan berdasarkan distribusi frekuensi disajikan pada Tabel 2.

Tabel 2 Hasil pengamatan aktivitas belajar siswa pada akhir Siklus I

\begin{tabular}{clcc}
\hline No & \multicolumn{1}{c}{ Indikator } & Jumlah & Persentase \\
\hline 1 & Siswa membentuk kelompok-kelompok diskusi & 10 & $100,0 \%$ \\
2 & Siswa berani menjawab pertanyaan dari guru & 5 & $50,0 \%$ \\
3 & Siswa membaca materi yang akan didiskusikan & 6 & $60,0 \%$ \\
4 & Siswa mencatat hasil diskusi & 6 & $60,0 \%$ \\
5 & Siswa berpartisipasi aktif dalam diskusi & 6 & $60,0 \%$ \\
6 & Siswa mampu menyusun laporan hasil diskusi & 6 & $60,0 \%$ \\
7 & Siswa mampu menyajikan hasil diskusi di depan kelas & 5 & $50,0 \%$ \\
8 & Siswa mampu menulis kesimpulan & 6 & $60,0 \%$ \\
\hline
\end{tabular}

Selain pengamatan pada aktivitas siswa selama kegiatan pembelajaran. Guru juga melakukan evaluasi hasil belajar dalam bentuk tes. Hasil belajar siswa disajikan pada Tabel 3 .

Tabel 3 Hasil penelitian pada Siklus I

\begin{tabular}{|c|c|c|c|c|}
\hline No & Nama Siswa & KKM & Nilai & Keterangan \\
\hline 1 & Bunga Rahmanora & 65,00 & 50,00 & Tidak Tuntas \\
\hline 2 & Dela Juliana & 65,00 & 70,00 & Tuntas \\
\hline 3 & Indah Rahayu Dwi Putri & 65,00 & 60,00 & Tidak Tuntas \\
\hline 4 & Kevin Isra Maulana & 65,00 & 50,00 & Tidak Tuntas \\
\hline 5 & Pazila Satrianis & 65,00 & 80,00 & Tuntas \\
\hline 6 & Putri Habibah & 65,00 & 80,00 & Tuntas \\
\hline 7 & Putri Silvi Ramadani & 65,00 & 50,00 & Tidak Tuntas \\
\hline 8 & Radit Gustira & 65,00 & 70,00 & Tuntas \\
\hline 9 & Rahmat Hadi Pratama & 65,00 & 70,00 & Tuntas \\
\hline \multirow[t]{5}{*}{10} & Zafit Wahyu Oktoria & 65,00 & 80,00 & Tuntas \\
\hline & Nilai Tertinggi & & 80,00 & \\
\hline & Nilai Terendah & & 50,00 & \\
\hline & Nilai Rata-Rata & & 66,00 & \\
\hline & Ketuntasan Belajar & & $60,00 \%$ & \\
\hline
\end{tabular}


Hasil penelitian yang disajikan pada Tabel 3 menunjukkan bahwa nilai terendah siswa adalah sebesar 50 dan nilai tertinggi siswa adalah sebesar 80. Nilai rata-rata yang diperoleh siswa adalah sebesar 66,0. Niai rata-rata yang diperoleh siswa setelah diberikan tindakan (pembelajaran dengan metode diskusi) mengalami peningkatan. Nilai rata-rata yang diperoleh siswa pada pratindakan sebesar 54,0. Setelah pelaksanaan Siklus I, nilai ini mengalami peningkatan sebesar 12,0 point menjadi 66,0. Selain peningkatan nilai rata-rata, peningkatan juga terjadi pada ketuntasan belajar siswa. Hasil evaluasi Siklus I menunjukkan bahwa ketuntasan belajar siswa yang awalnya adalah 30,0\% pada pratindakan meningkat menjadi $60,0 \%$ pada Siklus I. Hasil ini mengindikasikan bahwa terjadi perubahan hasil belajar setelah diberikan tindakan berupa metode diskusi. Dengan demikian, penggunaan metode ini perlu dilanjutkan pada siklus selanjutnya.

Keempat, refleksi. Refleksi dari hasil penelitian adalah sebagai berikut:

1. Memperbaiki perangkat pembelajaran

2. Mendampingi siswa dalam diskusi terutama pada siswa yang belum berpartisipasi aktif pada Siklus I

3. Memberikan motivasi pada siswa agar berani menyampaikan pendapatnya dan berani menyajikan hasil diskusi di depan kelas

4. Merumuskan tindakan siklus II berdasarkan temuan pada siklus I.

\section{Siklus II}

Kegiatan penelitian pada siklus II dilaksanakan pada hari Kamis, 22 September 2016 (Pertemuan ke-1 Siklus II), hari Kamis, 29 September 2016 (Pertemuan ke-2 Siklus II), dan hari Sabtu, 1 Oktober 2016 (Evaluasi Hasil Belajar Siklus II). Kegiatan penelitian pada siklus II terdiri atas perencanaan, pelaksanaan, pengamatan, dan refleksi.

Pertama, perencanaan. Kegiatan perencanaan terdiri atas: merumuskan tujuan pembelajaran, memilih dan mengorganisasi materi ajar, memilih sumber belajar/media pembelajaran, menyusun skenario/kegiatan pembelajaran, dan menyiapkan alat evaluasi hasil belajar.

Kedua, pelaksanaan. Penelitian tindakan kelas dilakukan pada pembelajaran Pendidikan Kewarganegaraan khususnya sub-materi dari Sistem Pemerintahan Republik Indonesia yaitu Pemilihan Umum, Pemilihan Presiden dan Wakil Presiden, serta Pemilihan Kepala Daerah dan Wakil Kepala Daerah. Materi yang disampaikan dalam siklus II adalah Pemilihan Presiden dan Wakil Presiden (pertemuan ke-1 Siklus II) dan Pemilihan Kepala Daerah dan Wakil Kepala Daerah (pertemuan ke-2 Siklus II). Kegiatan dilaksanakan dalam tiga tahap yaitu kegiatan awal, kegiatan inti, dan kegiatan akhir. Kegiatan awal, terdiri atas: guru mengucapkan salam dan menanyakan keadaan siswa, guru mengecek kehadiran siswa, guru menyampaikan tujuan pembelajaran, dan guru menyampaikan skenario pembelajaran yang akan dilaksanakan. Kegiatan inti, terdiri atas: guru menjelaskan masalah yang akan didiskusikan, siswa membentuk kelompok dengan anggota 4-5 orang dan menunjuk satu orang siswa untuk menjadi pemimpin diskusi, siswa melakukan diskusi secara berkelompok, guru mendampingi siswa selama kegiatan diskusi berlangsung, siswa membuat laporan tentang hasil diskusi, setiap perwakilan kelompok menyampaikan hasil diskusi ke depan kelas, dan siswa menanggapi presentasi kelompok lain. Kegiatan penutup, terdiri atas: guru bersama siswa membuat kesimpulan pembelajaran, guru menyampaikan gambaran materi pelajaran selanjutnya, guru menyampaikan pesan moral.

Ketiga, pengamatan. Secara ringkas, hasil pengamatan menunjukkan bahwa siswa telah membentuk kelompokkelompok diskusi. Kelompok yang 
terbentuk terdiri atas dua kelompok yang setiap kelompok beranggotakan lima orang siswa. Setiap kelompok juga telah memilih salah satu siswa sebagai ketua kelompok dan pemimpin diskusi. Sebagian besar siswa telah berani untuk menyampaikan pendapatnya untuk menjawab pertanyaan yang diberikan oleh guru. Akan tetapi, masih terdapat dua orang siswa tidak berani unttuk menyampaikan pendapatnya dalam menjawab pertanyaan guru. Dengan demikian, guru perlu memberikan bimbingan pada siswa dalam menjawab pertanyaan. Seluruh siswa juga telah membaca materi yang akan didiskusikan bersama teman sekelompoknya. Sebagian besar siswa telah berpartisipasi aktif dalam kegiatan diskusi.Sebagian besar siswa telah mampu mencatat hasil dari diskusi yang dilakukan. Semua kelompok telah mampu menyusun hasil diskusi dan mengumpulkan hasil diskusi ke guru. Sebagian besar siswa telah berani untuk mempresentasikan hasil diskusi di depan kelas. Sebagian besar siswa telah mampu menuliskan kesimpulan pembelajaran. Hasil pengamatan berdasarkan distribusi frekuensi disajikan pada Tabel 4.

Tabel 4 Hasil pengamatan aktivitas belajar siswa pada akhir Siklus II

\begin{tabular}{clcc}
\hline No & \multicolumn{1}{c}{ Indikator } & Jumlah & Persentase \\
\hline 1 & Siswa membentuk kelompok-kelompok diskusi & 10 & $100,0 \%$ \\
2 & Siswa berani menjawab pertanyaan dari guru & 8 & $80,0 \%$ \\
3 & Siswa membaca materi yang akan didiskusikan & 10 & $100,0 \%$ \\
4 & Siswa mencatat hasil diskusi & 8 & $80,0 \%$ \\
5 & Siswa berpartisipasi aktif dalam diskusi & 8 & $80,0 \%$ \\
6 & Siswa mampu menyusun laporan hasil diskusi & 8 & $80,0 \%$ \\
7 & Siswa mampu menyajikan hasil diskusi di depan kelas & 8 & $80,0 \%$ \\
8 & Siswa mampu menulis kesimpulan & 8 & $80,0 \%$ \\
\hline
\end{tabular}

Selain pengamatan pada aktivitas siswa selama kegiatan pembelajaran. Guru juga melakukan evaluasi hasil belajar dalam bentuk tes. Hasil belajar siswa disajikan pada Tabel 5. Hasil penelitian menunjukkan bahwa nilai terendah siswa adalah sebesar 60,0 dan nilai tertinggi siswa adalah sebesar 90,0. Nilai rata-rata yang diperoleh siswa adalah sebesar 76,0. Niai rata-rata yang diperoleh siswa setelah diberikan tindakan (pembelajaran dengan metode diskusi) mengalami peningkatan. Setelah pelaksanaan Siklus I, nilai rata-rata siswa mengalami peningkatan sebesar 22,0 point dibandingkan dengan nilai rata-rata pada pratindakan yaitu 54,0. Apabila dibandingkan dengan hasil pada siklus I, nilai rata-rata meningkat sebesar 10 point dibandingkan dengan nilai rata-rata pada siklus I yang sebesar 66,0. Selain peningkatan nilai rata-rata, peningkatan juga terjadi pada ketuntasan belajar siswa. Hasil evaluasi Siklus II menunjukkan bahwa ketuntasan belajar siswa yang awalnya adalah $30,0 \%$ pada pratindakan meningkat menjadi $60,0 \%$ pada Siklus I, dan kembali meningkat menjadi $80,0 \%$ pada siklus II. Hasil ini mengindikasikan bahwa terjadi perubahan hasil belajar setelah diberikan tindakan berupa metode diskusi. Dengan demikian, metode diskusi berhasil meningkatkan hasil belajar siswa kelas VI SDN. No. 035/XI Larikkemahan tahun 2016/2017.

Tabel 5 Hasil penelitian pada Siklus II

\begin{tabular}{clccl}
\hline No & Nama Siswa & KKM & Nilai & Keterangan \\
\hline 1 & Bunga Rahmanora & 65,00 & 70,00 & Tuntas \\
2 & Dela Juliana & 65,00 & 80,00 & Tuntas
\end{tabular}




\begin{tabular}{|c|c|c|c|c|}
\hline 3 & Indah Rahayu Dwi Putri & 65,00 & 70,00 & Tuntas \\
\hline 4 & Kevin Isra Maulana & 65,00 & 60,00 & Tidak Tuntas \\
\hline 5 & Pazila Satrianis & 65,00 & 90,00 & Tuntas \\
\hline 6 & Putri Habibah & 65,00 & 80,00 & Tuntas \\
\hline 7 & Putri Silvi Ramadani & 65,00 & 60,00 & Tidak Tuntas \\
\hline 8 & Radit Gustira & 65,00 & 80,00 & Tuntas \\
\hline 9 & Rahmat Hadi Pratama & 65,00 & 90,00 & Tuntas \\
\hline 10 & Zafit Wahyu Oktoria & 65,00 & 80,00 & Tuntas \\
\hline & Nilai Tertinggi & & 90,00 & \\
\hline & Nilai Terendah & & 60,00 & \\
\hline & Nilai Rata-Rata & & 76,00 & \\
\hline & Ketuntasan Belajar & & $80,00 \%$ & \\
\hline
\end{tabular}

Keempat, refleksi. Refleksi dari hasil penelitian adalah sebagai berikut:

1. Guru perlu memberikan bimbingan intensif pada siswa yang memperoleh hasil belajar kurang dari KKM Kompetensi Dasar pada evaluasi hasil belajar Siklus II

2. Guru perlu meningkatkan kompetensi diri sebagai upaya untuk meningkatkan kualitas pembelajaran

3. Guru perlu menggunakan metode pembelajaran yang bervariasi sebagai upaya untuk meningkatkan antusias siswa dalam kegiatan pembelajaran

4. Guru perlu meningkatkan kemampuan siswa dalam memahami bahan bacaan.

5. Hasil penelitian ini menjadi dasar guru dalam menyusun perencanaan untuk pembelajaran selanjutnya.

\section{Analisis Hasil Belajar Siswa}

Penelitian ini bertujuan untuk meningkatkan hasil belajar siswa pada mata pelajaran pendidikan kewarganegaraan di kelas VI SDN. No. 035/XI Larikkemahan tahun 2016/2017 dengan metode diskusi. Variabel yang diukur dalam penelitian ini adalah hasil belajar. Kegiatan penelitian diawali dengan tes penjajakan (pratindakan) sebagai acuan dalam menilai keberhasilan pembelajaran. Hasil tes penjajakan menunjukkan bahwa sebagain besar siswa belum mampu memenuhi nilai KKM Kompetensi Dasar pada mata pelajaran pendidikan kewarganegaraan yang sebesar 65,0.

Hasil penelitian terdahulu menyebutkan bahwa salah satu upaya yang dapat dilakukan oleh guru dalam meningkatkan hasil belajar siswa pada mata pelajaran Pendidikan Kewarganegaraan adalah dengan menggunakan metode diskusi. Metode diskusi diterapkan melalui penelitian tindakan kelas dalam dua siklus yaitu Siklus I dan siklus II. Evaluasi hasil belajar yang telah dilakukan pada Siklus I dan Siklus II menunjukkan hasil yang memuaskan. Nilai yang diperoleh siswa baik dari segi nilai rata-rata maupun persentase ketuntasan belajar mengalami peningkatan. Nilai rata-rata siswa yang awalnya 54,0 meningkat menjadi 66,0 pada Siklus I, dan kembali meningkat menjadi 76,0 pada Siklus II. Demikian juga halnya dengan persentase ketuntasan belajar. Persentase ketuntasan belajar siswa yang awalnya $30,0 \%$ meningkat menjadi $60,0 \%$ pada Siklus I dan kembali meningkat menjadi 80,0\% pada Siklus II. Rekapitulasi hasil belajar siswa pada saat pratindakan, siklus I, dan siklus II disajikan pada Gambar 1. 


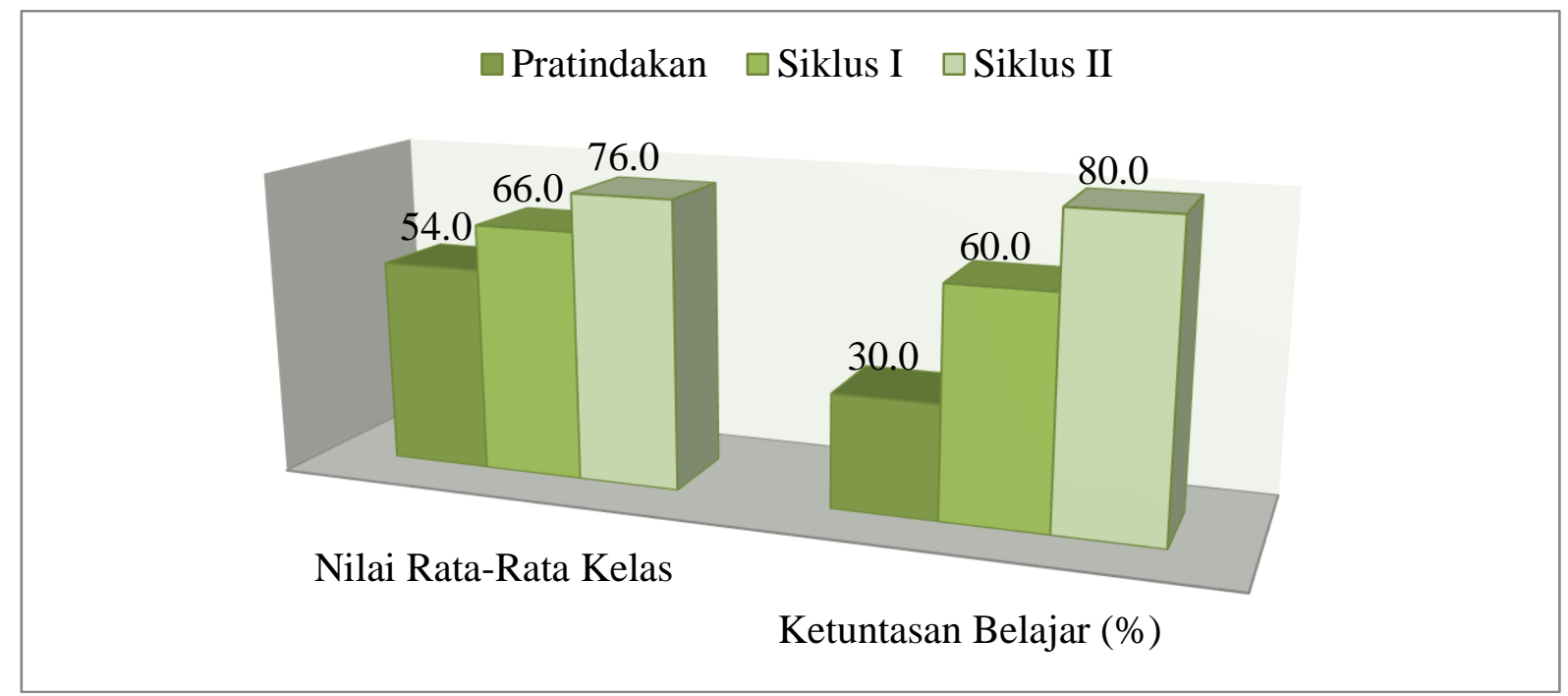

Gambar 1 Rekapitulasi hasil belajar siswa pada saat pratindakan, siklus I, dan siklus II

Hasil penelitian menunjukkan bahwa metode diskusi berhasil meningkatkan hasil belajar siswa kelas VI SDN. No. 035/XI Larikkemahan tahun 2016/2017 pada mata pelajaran Pendidikan Kewarganegaraan. Hasil penelitian ini mendukung hasil penelitian Asniar, Harun, dan Septiwiharti (2013) yang menemukan bahwa penggunaan metode diskusi di kelas V SD Inpres 3 kayu agung dapat meningkatkan hasil belajar Pendidikan Kewarganegaraan. Temuan ini juga menguatkan temuan Astute, Imran, \& Septiwiharti (2014) yang menemukan bahwa metode diskusi dapat meningktkan hasil belajar siswa pada pelajaran PKn di kelas III SD Inpres Banpres Posona. Temuan ini juga mendukung temuan Ahadang, Saneba, \& Hasdin (2014) yang menyatakan bahwa metode diskusi dapat digunakan dalam proses pembelajaran untuk meningkatkan hasil belajar siswa pada Mata Pelajaran Pendidikan Kewarganegaraan di Kelas IV SDN Palabatu 1.

Mirniati (2015) juga telah membuktikan bahwa metode diskusi dapat meningkatkan hasil belajar siswa pada mata pelajaran Pendidikan Kewarganegaraan di Kelas V SDN Inpres 3 Tolai. Demikian juga halnya dengan temuan Sumarni, Harun, dan Imran (2015) yang menyebutkan bahwa penerapan metode diskusi dapat meningkatkan hasil belajar siswa kelas IV Sekolah Dasar Kecil Toraranga pada mata pelajaran Pendidikan Kewarganegaraan. Menurut Firawati, Imran, dan Septiwiharti (2014), metode diskusi tidak hanya efektif dalam meningkatkan hasil belajar siswa pada bidang studi Pendidikan Kewarganegaraan di kelas V SD Inpres 2 Tada tetapi juga efektif dalam meningkatkan aktivitas siswa dalam kegiatan pembelajaran.

Salah satu dampak positif dari penggunaan metode diskusi dalam kegaiatn pembelajaran adalah metode ini dapat meningkatkan perhatian siswa dalam kegiatan pembelajaran. Amu, Jamaludin, dan Hasdin (2014) telah membuktikan bahwa metode diskusi dapat meningkatkan perhatian siswa kelas V SDN 2 Salakan pada mata pelajaran Pendidikan Kewarganegaraan melalui metode diskusi. Selain itu, metode diskusi juga dapat meningkatkan minat siswa daam belajar. Temuan Lanasir, Palimbong, dan Hasdin (2014) menyebutkan bahwa penerapan metode diskusi dapat meningkatkan minat belajar siswa kelas III B SDN Pembina Salakan Kecamatan Tinangkung Kabupaten Banggai Kepulauan. Peningkatan minat belajar pada siswa mendorong siswa untuk belajar lebih giat 
dan rajin sehingga peningkatan minat ini berdampak positif pada peningkatan hasil belajar siswa. Metode diskusi juga sangat membantu dalam meningkatkan pemahaman siswa. Menurut Libuka, Palimbong, dan Jamaludin (2014), metode diskusi dapat meningkatkan pemahaman siswa pada pembelajaran Pendidikan Kewarganegaraan di kelas IV SDN Tolulos Kecamatan Peling Tengah. Dengan demikian, metode diskusi dapat menajdi alternatif metode yang dapat digunakan guru dalam meningkatkan hasil belajar siswa.

\section{SIMPULAN}

Hasil penelitian menunjukkan bahwa metode diskusi berhasil meningkatkan hasil belajar siswa kelas VI SDN. No. 035/XI Larikkemahan tahun 2016/2017 pada mata pelajaran Pendidikan Kewarganegaraan. Nilai rata-rata siswa yang awalnya 54,0 meningkat menjadi 66,0 pada Siklus I, dan kembali meningkat menjadi 76,0 pada Siklus II. Demikian juga halnya dengan persentase ketuntasan belajar. Persentase ketuntasan belajar siswa yang awalnya $30,0 \%$ meningkat menjadi $60,0 \%$ pada Siklus I dan kembali meningkat menjadi $80,0 \%$ pada Siklus II. Berdasarkan hasil penelitian, penelitian ini menyarankan guru untuk meningkatkan kualitas pembelajaran dengan cara meningkatkan kompetensi diri; memilih dan menggunakan metode, model, dan strategi pembelajaran yang tepat dan beragam; menggunakan metode diskusi sebagai alternatif untuk meningkatkan hasil belajar siswa pada mata pelajaran Pendidikan Kewarganegaraan; dan memberikan motivasi untuk meningkatkan kepercayaan diri pada siswa.

\section{DAFTAR PUSTAKA}

Ahadang, A. H., Saneba, B., \& Hasdin. 2014. Meningkatkan Hasil Belajar Siswa Pada Mata Pelajaran PKn di Kelas IV SDN Palabatu 1 Melalui Metode Diskusi. Jurnal Kreatif
Tadulako Online Vol. 2 No. 3, 134141.

Amu, T. D. N., Jamaludin, \& Hasdin. 2014. Meningkatkan Perhatian Siswa Kelas V SDN 2 Salakan Pada Mata Pelajaran PKn Melalui Metode Diskusi. Jurnal Kreatif Tadulako Online Vol. 2 No. 3. 89-103.

Asniar, Harun, A. H., \& Septiwiharti, D. 2013. Peningkatan Hasil Belajar Siswa Melalui Metode Diskusi Pada Pembelajaran PKn Kelas V SD Inpres 3 Kayu Agung. Jurnal Kreatif Tadulako Online Vol. 1 No. 1,153-161. Astute, H. Y., Imran, \& Septiwiharti, D. 2014. Meningkatkan Hasil Belajar Siswa Pada Pelajaran PKn Dengan Menggunakan Metode Diskusi Di Kelas III SD Inpres Banpres Posona. Jurnal Kreatif Tadulako Online Vol. 2 No. 1, 113-126.

Dimyati dan Mudjiono. 2013. Belajar dan Pembelajaran. Cetakan kelima. Jakarta: Rineka Cipta.

Djamarah, S. B., \& Zain, A. 2006. Strategi Belajar Mengajar. Jakarta: Rineka Cipta

Firawati, Imran, \& Septiwiharti, D. 2014. Peningkatan Aktivitas Belajar Siswa Melalui Metode Diskusi Pada Bidang Studi PKn Di Kelas V SD Inpres 2 Tada. Jurnal Kreatif Tadulako Online Vol. 2 No. 4, 1-15.

Hosnan, M. 2014. Pendekatan Saintifik dan Kontekstual Dalam Pembelajaran Abad 21. Bogor: Ghalia Indonesia

Irham, M., \& Wiyani, N. A. 2013. Psikologi Pendidikan: Teori dan Aplikasi dalam Proses Pembelajaran. Yogyakarta: Ar Ruzz Media.

Kaelan. 2016. Pendidikan Kewarganegaraan untuk Perguruan Tinggi. Yogyakarta: Paradigma

Lanasir, J., Palimbong, A., \& Hasdin. 2014. Meningkatkan Minat Belajar Siswa Pada Pembelajaran PKn Melalui Metode Diskusi di Kelas III SDN Pembina Salakan Kecamatan Tinangkung Kabupaten Banggai 
Kepulauan. Jurnal Kreatif Tadulako

Online Vol. 2 No. 3, 154-163.

Libuka, B., Palimbong, A., \& Jamaludin. 2014. Meningkatkan Pemahaman Siswa Pada Pembelajaran Pkn Melalui Metode Diskusi Di Kelas IV SDN Tolulos Kecamatan Peling Tengah. Jurnal Kreatif Tadulako Online Vol. 2 No. 2, 142-156.

Mirniati, N. K. 2015. Meningkatkan Hasil Belajar Siswa Melalui Metode Diskusi Pada Mata Pelajaran PKn Tentang Menghargai Dan Menaati Keputusan Bersama Kelas V SDN Inpres 3 Tolai. Jurnal Kreatif Tadulako Online Vol. 3 No. 3, 112-124.

Rusman. 2011. Model-model Pembelajaran. Rajawali Press. Jakarta.

Slameto. 2010. Belajar dan Faktor-Faktor yang Mempengaruhi. Jakarta: Rineka cipta

Sudijono, A. 2005. Pengantar Evaluasi Pendidikan. Jakarta: Raja Grafindo Persada.

Sudjana, N. 2005. Penilaian Hasil Proses Belajar Mengajar. Bandung: Remaja Rosdakarya.

Sugiyono \& Hariyanto. 2011. Belajar dan Pembelajaran: Teori dan Konsep Dasar. Bandung: Remaja Rosdakarya.

Sumarni, Harun, A. H., \& Imran. 2015. Penerapan Metode Diskusi Untuk Meningkatkan Hasil Belajar Siswa Kelas IV Sekolah Dasar Kecil Toraranga Pada Mata Pelajaran PKn Pokok Bahasan Sistem Pemerintahan Kabupaten, Kota dan Provinsi. Jurnal Kreatif Tadulako Online Vol. 3 No. 4, 13-22. 